\title{
AUPF
}

\section{An Asian Disruptive Collaboration for the "Now" Generation, Why Not?}

\author{
Paul Nugraha \\ Petra Christian University, Indonesia \\ Email: pnugraha@petra.ac.id
}

\section{The "Now" Generation}

The present young generation in Indonesia recently use the nickname of the "now" generation, or the "now" era, which is somehow similar with the more popular term "digital natives" (Prensky, 2001). The term "now" refers to something which is totally different, and not connected to the past.

When the "now" generation of students come to class, most of them do not bring any book nor any note, not even a pen! They just bring a sole but powerful device, the smartphone. In the classroom or anywhere they go, they are always busy with it. They usually do multitasking \& parallel processes like chatting, texting, searching, while constantly bombarded with games, music, videos and social media. When they study or write a paper, all gadgets are turned on simultaneously: the computer to work on, stereos, television, and off-course the smartphone to keep getting connected. All the gadgets are in function at once.

\section{Their Problems with The Traditional Lectures}

The "now" generation are used to multi-tasking, switching fast from one option to another. They could not concentrate for long, especially when they can't get the sense/relevance out, to catch the main idea of the particular topic. If it does not ring a bell, they are easily distracted, lost. They have much shorter span of attention, can get easily restless or bored. They seem to be listening to the lecture, while actually they are doing other things as well.

The "now" generation are used to be bombarded through all their senses: sounds, moving pictures. Auditory alone without any media to see, like a plain lecture, especially when it doesn't make a sense, is unbearable.

The "now" generation wants things now, immediately. The smartphone always gives them immediate responses to cater their need. When they forget to bring something, the Gojek, online service will readily bring it to them. They are very impatient, 'Long waiting' is not in their vocabulary. The same principle goes to the classroom. Long monotonous lecture, no way. Preparatory or introductory course, no way. They can always get straight answer from Mr. Google, or madam Wiki. They definitely want the direct answer too from the lecture, straight forward answers.

The "now" generation feel they can climb every wall, fight every opponent, play any sport with their gadget. With this in mind, they expect the same case with the course and the whole study. During the process, they expect to face dilemmatic options to choose, puzzles to 


\section{AUPF}

unravel, obstacles to overcome, but their milestones have to be clearly defined. This enables them to check their achievements and go for the next step. Through the social media, they also can go viral, be instantly famous, or instantly rich. So be it also with their future career!

\section{Their Problems with On-line Courses}

The on-line courses, including the Massive Open Online Courses (MOOCs), popularized by the digital disruption, are good alternatives. It is more prestigious, since some of them are offered by the top-notch universities in the world, and yet are accessible and almost free. It is supposed to attract a lot of students from all over the world. That's why Christensen called it as a Disruptive Innovation in learning. It is also good because it opens the potentials to reduce/bridge the widening gap of the Digital Divide, the gap between the rich and the poor (countries).

But the question is, can the "now" generation make use of it successfully? Logically, they should, since they are already familiar with the technology. But sadly it is a different story in reality. Though many are applying, only a few that succeed. Why? Kennedy \& Fox (2013) mentioned that "They used a wide range of technologies ... but not always digitally literate in using technology to support their learning." Flavin (2012) mentioned that "there is no evidence to suggest that a wide range of technologies is being used to support learning and teaching. Students and lecturers do not depend on their institutions to support learning and teaching. Instead, they self-select technologies." Those few who succeed are those who are mature enough, who can handle, manage the digital technologies as a tool, while the rest of the majority are rather under the spell, distracted, addicted, mesmerized.

\section{Let's Break the Spell}

Let us help the majority of the "now" generation students, who are facing either the regular or the on-line courses. Let us break the spell, bridging the gap, empowering them to take charge, to make use the digital technology smartly, rather than being engulfed, enslaved. Let us wake them up from the spoiled overprotection, to stand on their own feet to direct their own destiny, facing up the difficulties and challenges.

They might still need some assistance, so let's help them with bridging courses, tutorials, translated materials, matriculation classes, peer2peer learning, sensitisation before admission about employability pathway, career counselling after induction, career support upon graduation, and so forth. Let them build their own self-awareness of needs, self-regulation skills, self-discipline, and self-evaluating sense (Kanwar, 2018)

Three other things can be done to make it fitter to the need of the future. The first one is modifying the delivery of the course, the second is modifying the diploma package, and the third is cultivate your own unique courses/programs. 


\section{Make Lectures More Fun and Attractive}

Lecturers should learn from the games, how it attracts the "now" generation. First, it is a fun challenge with lots of graphics, animations and sounds. This will attract the students and without much pressure they will be easily absorbed in the game-like concept. Second, it is exploring, step by step. Not too difficult to be confusing, and not too easy to be boring. Third, getting immediate feedback, including the reward and penalty will help the students to know their position and they will be challenged to figure out strategy to go to the next step. Similar to the game, there is also another live to start.

So why not modify the lectures with something like "gamification" concept (Urh et al, 2015), applying game design elements and principles in non-game contexts by increasing participation, engagement, loyalty and competition. First, put lot of graphics and animations to clarify things, explain an abstract idea or emotions/expressions. Second, divide the long lecture into shorter chewable bites. Not the long never-ending dreading lectures, and then let them explore. Give them problem or puzzle to solve right after lecture. Don't wait until midterm. Third, give them feedback on the next meeting. Quick review and give acknowledgment and bonus to the best group work. If you have a small class, you can design the course in such a way that each student can proceed with their own pace. And give them bonuses if they can handle harder problems.

\section{Create Shorter Packages and Rearrange}

The face of education is changing. Graduates will be switching on and off between school and jobs, because of the fast continuing changes in technology tools \& processes, and they will be facing multiple jobs \& career throughout lifetime.

For their first job position, they just need Just-In-Time, Just-Enough learning, technical courses for the job position with which they immediately can apply. Later on, when they are promoted to higher positions, then, they have to go to class again to be equipped with further courses, or getting updated with the latest technical development. It is a switching processes between campus and work.

In that case, the degrees or credentials should be made in shorter duration, in modular approach and skill-based. Problem of accreditation in the future might be overcome by something like block-chain for credentialing, in which entries cannot be modified (Kanwar, 2018).

It might be inappropriate to stuff them up at once with all the knowledge and skills which we think they will need in the future. In Engineering field, for example, the curriculum should concentrate more on the technicalities, which will be the job of the junior engineer when they enter the position as undergraduate. Later when they are promoted to be a coordinator, then and only then they need another course of management and leadership. Later on, when they face global competition, they need another macro thinking course. Not the other way around! Usually we put the not-needed general management in the first semester, and the needed construction management later in the fourth or fifth semester. 


\section{Cultivate Your University Uniqueness}

In this global competitive world, the top-notch universities become real challenge to smaller ones, especially when they offer free on-line courses. However, each Asian university has its own uniqueness. Cultivating the uniqueness, either excellent programs, or distinctive heritage, local content with local wisdom is advisable (Tian \& Dong, 2017). Eyring and Christensen (2011) recommend that "traditional universities adopt a pattern of continuous innovation focused on their unique mission."

One way of doing it is through glocalization. Patel and Lynch (2013) mentioned that "Glocal and glocalization refer to the merger of global and local perspectives of all phenomenon that affects local and global communities. Glocalization advocates a positive learning experience and encourages the enhancement of learners' glocal experience through a critical academic and cultural exchange of global and local socio-economic and political issues."

\section{Sharing Strengths and Uniqueness}

So why don't Asian Universities share the Uniqueness? They have worked hard to make excellent \& unique courses or programs, so why keeping it only for their own students, how about sharing it to the bigger audience, the whole Asia, or even globally. It will be a mutual symbioses. And each university will share through some cooperation, networking, interaction, and if necessary: 'Coopetion', both cooperation and competition at the same time. Looking back at Digital Disruption that already happened (Pereira, 2015):

- World largest taxi company own no taxis (Uber)

- Largest accommodation providers own no real estate (AirBnb)

- Most popular media owner creates no content (Facebook)

- World's largest movie house owns no cinemas (Netflix)

we can see emerging new digital companies which actually having no real assets, but the technology enables them to coordinate people to share resources. This is the key. The anomalies happens because the people share the usage of the taxis, rooms, media and movies.

There are some examples of university collaboration from US: "The Next Disruption in Higher Education is Collaboration," a speech Michael Crow, president of Arizona State University delivered to University Innovation Alliance (UIA) members and guests in Washington DC. A sum of 43 urban public universities make a coalition of Urban Serving Universities (USU), committed to increase prosperity and opportunity in cities and to tackling key urban challenges. USU and Association of Public and Land-Grant Universities (APLU), supported by the Bill and Melinda Gates Foundation, collaborating to plan and implement transformational - although often disruptive - approaches to student success efforts. 


\section{And Let It Emerge into A Disruption}

One step further, let's start to collaborate, sharing our Asian strengths and uniqueness. At least we start the process. IF it is perceived by others as of lower quality, let's consider it okay for now. By definition of disruption characteristics, it is still in the initiation stage, and certainly will take some time to grow. By God's grace, let us all hope that it will be gradually snow-balling to be an Asian disruption!

\section{References}

Brown, M. (2015). Six Trajectories for Digital Technology in Higher Education. EduCause Review, June 22.

Burns, B., Crow, M., and Becker, M. (2015). Innovating Together: Collaboration as a Driving Force to Improve Student Success, EduCause Review, March 2, 2015.

Choudaha, R. (2012). The Rise of 'Glocal' Students and transnational education, The Guardian, Jun 21.

Eyring, H., Christensen, C.M. (2011). The Innovative University: Changing the DNA of Higher Education, Jossey Bass.

Flavin, M. (2012). Disruptive Technologies in Higher Education, Research in Learning Technology. Supplement: ALT-C 2012 Conference Proceedings.

Kanwar, A. (2018). Higher Education in an Age of Disruption, Keynote Address; Innovation Arabia 11. Dubai, United Arab Emirates.

Kennedy, D.M., Fox, B. (2013). 'Digital Natives': An Asian Perspective for Using Learning Technologies. International Journal of Education and Development using Information and Communication Technology (IJEDICT), 2013, Vol. 9, Issue 1, pp. 64-79.

Patel, F., Lynch, H. (2013), Glocalization as an Alternative to Internationalization in Higher Education: Embedding Positive Glocal Learning Perspectives, International Journal of Teaching and Learning in Higher Education., Volume 25, Number 2, pp 223-230.

Pereira, B. (2015). Preparing for Disruptive Collaboration. Retrieved from www.digitalcreed.in/preparing-for-disruptive-collaboration/ on 2018-09-10

Prensky, M. (2001). Digital Natives, Digital Immigrants, On the Horizon, Vol. 9, No. 5.

Tian, S., Dong, Y.L. (2017). Cultivation of Unique Campus Culture in Universities of Science and Engineering and Its Illuminations: Based on "Free Your Talent" Material Culture Festival in Wuhan University of Technology, 2nd International Conference on Modern Economic Development and Environment Protection (ICMED 2017).

Urh, M., et al (2015). The Model For Introduction Of Gamification Into E-Learning In Higher Education, Procedia - Social and Behavioral Sciences, 197 (2015) pp 388-397.

Collaboration of Urban Serving Universities and Association of Public Land-grant Universities (2015). Revolutionizing the Role of the University - Collaboration to Advance Innovation In Higher Education. Retrieved from http://www.aplu.org/library/revolutionizing-the-role-of-the-university/File 